\title{
Optimal Design of Hybrid Renewable Energy System for a Sustainable Energy Development of a Village in Rajasthan
}

\author{
Nirma Kumari Sharma ${ }^{1}$, Rahul Mishra ${ }^{2}$ \\ ${ }^{1}$ M.Tech Scholar, Mewar University, Chittorgarh \\ ${ }^{2}$ Assistant Professor Electrical Engineering Department, Mewar University, Chittorgarh
}

\begin{abstract}
This paper presents design of hybrid renewable energy system based on solar, biomass \& wind energy resources. The optimization is using HOMER software to get the best \& optimal operation system. Hybrid energy system is an excellent solution for power generation in rural areas where the grid extension is difficult \& uneconomical. Hybrid system combines several energy systems together, it can supply high reliable electricity rather than PV/battery system or a Wind/battery system. So this paper is mainly focused on the hybrid system which consists of wind ,PV/battery system ,bio-mass.The main reason for choosing bio-mass system have lot of potential to utilize. The main theme of this paper is to develop hybrid energy system (mainly includes bio-mass) \& develop optimal operating strategy. An optimization model has been developed for the optimal operation of the system. The system is modelling meteorological \& load data collected from a typical village. The optimal hybrid system design is realized by satisfying the load demand nonlinear seasonal variations \& equipment constraints. The simulations results were carried out using HOMER software.
\end{abstract}

Keywords: Biomass, Wind, PV, Hybrid system, rural areas, Optimization model, NPC, COE

\section{Introduction}

Energy is the ultimate factor which is responsible for industrial agriculture \& living -standard growth. The use of $\mathrm{RE}$ technology has been rapidly increasing to meet growing energy demand. But the main difficulty of using these renewable systems is that they cannot provide reliable electricity due to the intermittent nature of these resources.

Biomass is the Organic material, which has stored solar energy from sunlight in the form of chemical in the plants through the process called photosynthesis. Biomass fuels include agriculture wastes, crop residues, wood \& woody wastes, cow dung etc.

The main objective of this research is to find the best standalone configuration of hybrid renewable energy system in terms of optimum sizing \& strategy of operational aspect with solar energy \& biomass resources. Finally this research will evaluate the proposed hybrid renewable energy system in terms of the optimization and sensitivity analyses in order to get best combination or solution of the proposed system

\section{Methodology}

This paper mainly focuses on a photovoltaic -bio-mass, wind battery based system. The proposed RETs optimization model, which developed by hybrid optimization model for electric renewable (HOMER) software \& explains all elements of the prosed system.

\section{Renewable Energy Resources}

(A)Solar energy resources

The calculation of global horizontal solar radiations \& optimum size of the system which was based on the longitude
\& latitude $\left(74^{\circ} 42^{\prime} \mathrm{E}, 25^{\circ} 75^{\prime} \mathrm{N}\right)$ of assigned geographical region was done by HOMER. The village named Mandpiya is located at district Chittorgarh. The solar energy resources data was taken from official website of NASA surface meteorology \& solar energy website. HOMER calculates the monthly solar radiation based on the average solar radiation fig 1 shows the monthly annual average solar radiation \& clearness index. Annual average solar radiation reading of $3.67 \mathrm{kWh} / \mathrm{m}^{2} /$ day.

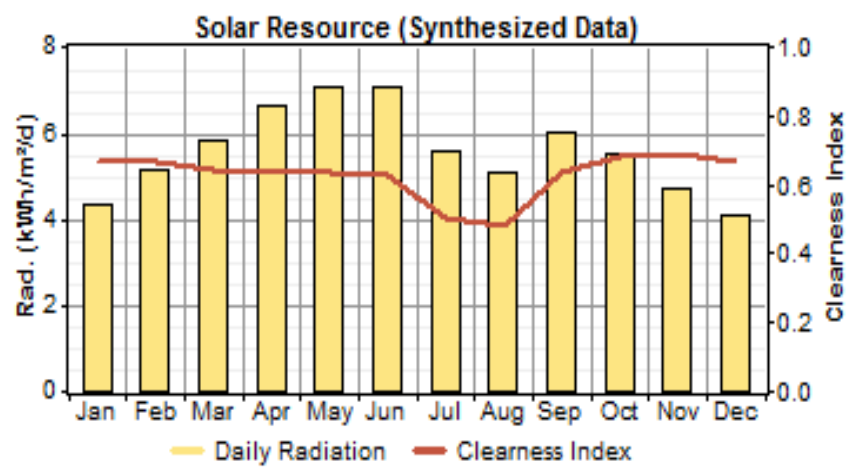

Fig 1 Monthly Solar radiation data

\section{(B) Biomass Resources}

Cattle dung has been used as fuel in the research as it is widely available for long time. Most abdunt energy is biomass which can be available more in villages /rural areas of India. At this location we can utilize the biomass potential. The total biomass potential generated per day in the village is around 6.7tons, so on an approximation bases monthly average biomass potential generated would be 203.85tons. So from the available resources we can analyze cost \& size combination of biomass generator as required by the load. 


\section{International Journal of Science and Research (IJSR) \\ ISSN (Online): 2319-7064}

Index Copernicus Value (2013): 6.14 | Impact Factor (2015): 6.391

Table 1: Biomass resources stock data

\begin{tabular}{|c|c|c|}
\hline Month & $\begin{array}{c}\text { Monthly stock } \\
\text { data(tons) }\end{array}$ & $\begin{array}{c}\text { Average daily } \\
\text { stock (tons) }\end{array}$ \\
\hline January & 203.85 & 6.7 \\
\hline February & 203.85 & 6.7 \\
\hline March & 203.85 & 6.7 \\
\hline April & 203.85 & 6.7 \\
\hline May & 203.85 & 6.7 \\
\hline June & 203.85 & 6.7 \\
\hline July & 203.85 & 6.7 \\
\hline August & 203.85 & 6.7 \\
\hline September & 203.85 & 6.7 \\
\hline October & 203.85 & 6.7 \\
\hline November & 203.85 & 6.7 \\
\hline December & 203.85 & 6.7 \\
\hline
\end{tabular}

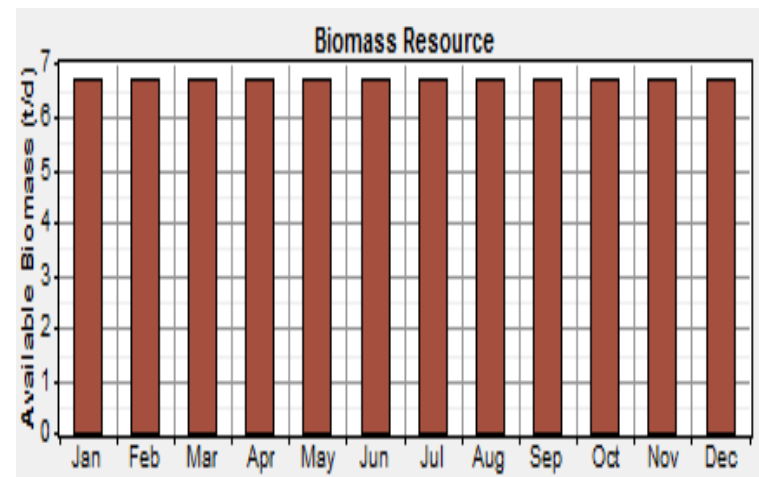

Figure 2: Biomass resources monthly stock

\section{(C) Load Demand Assessment}

The seasonal load assessment of summer \& winter was calculated based on minimum as well as desirable load profile. The total load requirement of the study area was found to be $163 \mathrm{kWh} /$ day while the peak load was $41 \mathrm{~kW}$. fig 3 shows the daily load profile generated by homer based on the hourly load.

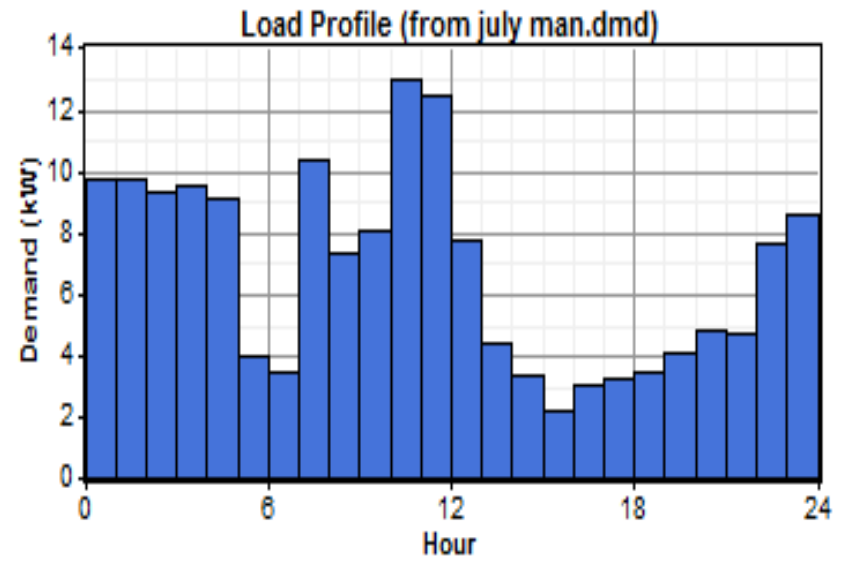

Figure 3: Load profile of the village

\section{(D) Wind Resources}

The wind speed is quite low in this region. The scaled annual average wind speed is $3.67 \mathrm{~m} / \mathrm{sec}$.; the wind speed variation is shown in fig 4.

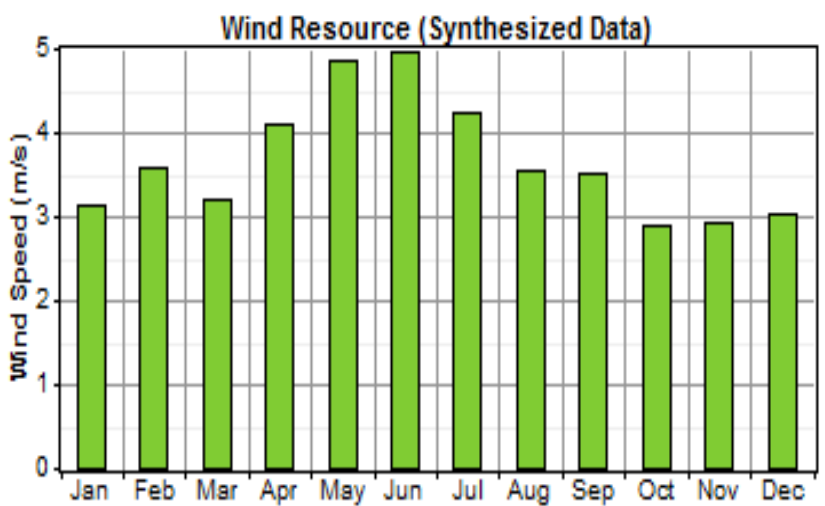

Fig 4 Monthly averaged wind speed

\section{Hybrid System Modelling}

The selected region receives substantial amount of solar radiation and wind energy throughout the year. The biomass demand is naturally fulfilled whole year. The annually available biomass potential is 2446.3 ton. So the monthly and daily potential of biomass is respectively 203.85tons and 6.7tons. Therefore combination of PV system, wind system and biomass system would be feasible for this region. A hybrid system with PV/Wind/Biomass/Battery bank has been selected for off-grid analysis. Then this hybrid system is modeled using micro grid optimization software "HOMER" as shown in fig 5. HOMER is a computer model that simplifies the task of evaluating design options for both offgrid connected power systems for remote, stand-alone and distributed generation application. This is the proposed hybrid system shown in fig 5 .

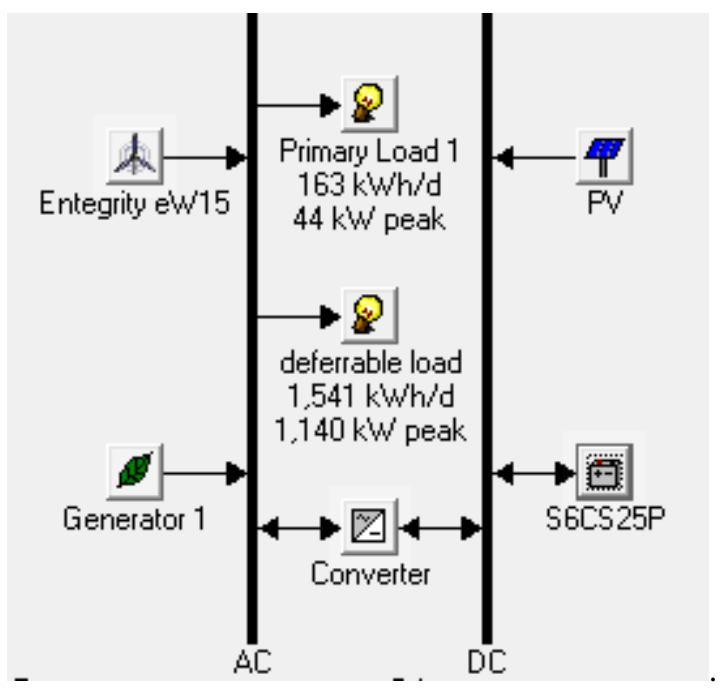

Figure 5: HOMER Hybrid model

(A) Homer input summary

Table II represent the summary of the costs, other technical details of the component and other required parameters which are considered as the input to the HOMER hybrid model. 


\section{International Journal of Science and Research (IJSR) \\ ISSN (Online): 2319-7064 \\ Index Copernicus Value (2013): 6.14 | Impact Factor (2015): 6.391}

Table 2: System Components cost

\begin{tabular}{|c|c|c|c|c|}
\hline Component & Size & $\begin{array}{c}\text { Capital } \\
\text { Cost }(\$)\end{array}$ & O \& M & $\begin{array}{c}\text { Replacement } \\
\text { Cost }(\$)\end{array}$ \\
\hline PV system & $10 \mathrm{~kW}$ & 26700 & $10 \$ /$ year & 2000 \\
\hline Wind turbine & $10 \mathrm{~kW}$ & 20000 & 500 /year & 20000 \\
\hline Battery & $360 \mathrm{Ah}$ & 450 & $10 \$ /$ year & 440 \\
\hline Converter & $30 \mathrm{~kW}$ & 23000 & $10 \$ /$ year & 23000 \\
\hline
\end{tabular}

\begin{tabular}{|l|l|l|l|l|}
\hline Generator & $1 \mathrm{~kW}$ & 2652 & $.1 \$ / \mathrm{hr}$. & 2652 \\
\hline & $10 \mathrm{~kW}$ & 5500 & $.5 \$ / \mathrm{hr}$. & 5475 \\
\hline & $21 \mathrm{~kW}$ & 6600 & $.6 \$ / \mathrm{hr}$. & 6600 \\
\hline & $30 \mathrm{~kW}$ & 8800 & $.8 \$ / \mathrm{hr}$. & 8000 \\
\hline
\end{tabular}

The load curve of the village is shown in fig 3.Even though a constant load profile has been assumed throughout the year. HOMER can add hourly and daily randomness to this daily load profile to make the load profile realistic. In addition HOMER can generate synthetic hourly solar radiation data and wind speed data based on the monthly average values.

\section{Results}

The optimization results of hybrid renewable energy systems developed using HOMER are shown in fig 6 . The system is having the lowest total net present value is optimum hybrid system configuration.

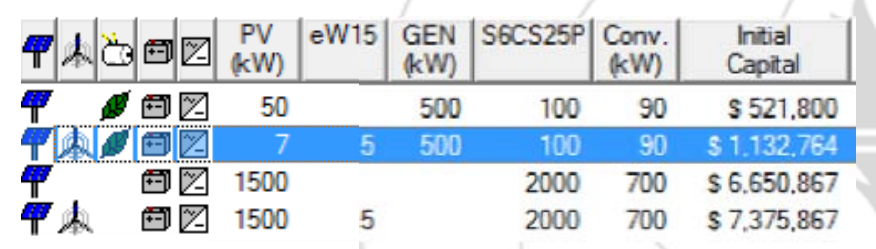

\begin{tabular}{|c|c|c|c|c|c|c|}
\hline 计四 & $\begin{array}{l}\text { Total } \\
\text { NPC }\end{array}$ & $\begin{array}{c}\mathrm{COE} \\
(\$ / \mathrm{kWh})\end{array}$ & $\begin{array}{l}\text { Ren. } \\
\text { Frac. }\end{array}$ & $\begin{array}{l}\text { Capacty } \\
\text { Shortage }\end{array}$ & $\begin{array}{c}\text { Biomass } \\
\text { (t) }\end{array}$ & $\begin{array}{l}\text { GEN } \\
\text { (hrs) }\end{array}$ \\
\hline t+- & $\$ 1,188,729$ & 0.154 & 1.00 & 0.05 & 1.676 & 2,569 \\
\hline$\square$ & $\$ 2,100,665$ & 0.272 & 1.00 & 0.05 & 1.719 & 2,691 \\
\hline 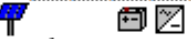 & $\$ 9,604,290$ & 1.237 & 1.00 & 0.03 & & \\
\hline 田 & $\$ 10,622,436$ & 1.362 & 1.00 & 0.03 & & \\
\hline
\end{tabular}

Figure 6: Optimization result

\section{Conclusion}

The optimization result of hybrid renewable energy systems are developed using HOMER software. For the energy supply problem in remote areas such as Mandpiya village we found out the feasible option for this village. Homer software was used for estimation of optimal size, least NPC and COE with different configuration of the IERS. Furthermore, the hybrid system, once it has been implemented has low O\&M costs. For these reason a standalone/ mini-grid hybrid system can be the most financially attractive and reliable solution. According to the simulation results, a hybrid system with $7 \mathrm{~kW}$ PV system, $5 \mathrm{~kW}$ wind system, $500 \mathrm{~kW}$ biomass generator and 100 batteries with the $90 \mathrm{~kW}$ converter system is found to be optimum configuration. The total net present cost of this project is \$ $2,100,665$ and it requires initial capital cost investment of \$ $1,132,764$ to implement the project. The annual capacity shortage of this system is $0.05 \%$. Sometime a compromise is made at the cost of COE, making simulation ineffective.
Sometime optimal configurations simulated by the software are not practically possible to install, hence compromise has to be made in favor of second or third most economical configuration.

\section{References}

[1] www.homerenergy.com

[2] http://homerenergy.com/pdf/homergettingstarted268.pdf

[3] www.weatherbase.com

[4] S. Ashok, \& P. Balamurugan, "Biomass Gasifier Based Hybrid Energy System for Rural Areas." (2007) pp 371375

[5] Kolhe M., K.M.Iromi Udumbara Ranaweera, A.G.B Sisara Gunawardana,“Techno-Economic Optimum Sizing Of Hybrid Renewable Energy System.” (2013) pp 1898-1903

[6] Ali Naci Celik, "Techno-economic analysis of autonomous PV-wind hybrid energy systems using different sizing methods," Energy Conversion and Management 44 (2003) 1951-1968.

[7] Anis Afazal ,Harish kumar,V.K.Sharma, "Hybrid Renewable Energy Systems For Energy Security Using Optimization Technique". (2012)

[8] Md.Moniruzzaman Tanim, Nawshad Ahmed Chowdhury ,Mirza Mahbubur Rahman, Jannatul Ferdous, Metropolitan University ,Sylhet, Bangladesh “ Design Of A Photovolatic -Biogas Hybrid Power Generation System For Bangladeshi Remote Area Using Homer Software".

[9] Rajanna S and R P Saini, Alternate Hydro Energy Centre IIT, Roorkee. "Optimal Modelling Of Solar/Biogas /Biomass Based IRE System for a Remote Area Electrification" (2014).

[10] Mohit Bansal, D.K.Khatod, R P Saini, Alternate Hydro Energy Centre IIT, Roorkee. "Modeling and Optimization Of Integrated Renewable Energy System For a Rural Site". (2014), Pp 25-28

[11] Ranipet Hafeez Basha, Shuichi Torii, “ Design of a computer model for simulation of combustion parameters of biomass using J2SE 5.0 Program" International Journal of Earth Sciences and Engineering, ISSN 0974-5904, Vol. No.1,pp 172-176

[12] Ahmad Rohani, Kazem Mazlumi, Hossein Kord, “ Modeling of a hybrid power system for economic analysis and environmental in Home," Electrical Engineering (ICEE),2010 $18^{\text {th }}$ Iranian Conference on ,pp.819-823,11-13 May 2010. 